\title{
Species Distribution, Diversity, and Abundance of Sea Cucumbers in Tropical Intertidal Zones of Aurora, Philippines
}

\author{
Maria Cristina B. Cañada, Michelle A. Resueño, Eusebio V. Angara \\ Research and Development Services Office, Aurora State College of Technology, Baler, Aurora, Philippines \\ Email: mariacristinacanada@ascot.edu.ph
}

How to cite this paper: Cañada, M.C.B., Resueño, M.A. and Angara, E.V. (2020) Species Distribution, Diversity, and Abundance of Sea Cucumbers in Tropical Intertidal Zones of Aurora, Philippines. Open Journal of Ecology, 10, 768-777. https://doi.org/10.4236/oje.2020.1012047

Received: October 30, 2020

Accepted: December 5, 2020

Published: December 8, 2020

Copyright $\odot 2020$ by author(s) and Scientific Research Publishing Inc. This work is licensed under the Creative Commons Attribution International License (CC BY 4.0).

http://creativecommons.org/licenses/by/4.0/

\begin{abstract}
The distribution, diversity, and abundance of sea cucumbers in intertidal zones of Aurora were studied from February to June 2013 to obtain baseline data. A one-hour timed-search survey covering an approximate one kilometer over a ten-meter wide area was conducted in six coastal municipalities to obtain a comprehensive list of sea cucumber species found in the zones. Only four sampling stations (Baler, Dipaculao, Dilasag, and Dingalan) were selected for belt transect survey, $50 \times 50 \mathrm{~m}$, based on the availability of coralline, sandy, muddy sand, and rocky habitats which were laid perpendicular and parallel to each intertidal zone. Timed-search survey revealed a total of 15 species of sea cucumbers distributed among two Orders (Order Aspidochirotida and Order Apodida) and four Families (Family Holothuriidae, Family Stichopodidae, Family Synaptidae, and Family Chirotidae) were recorded. Synapta maculata is most common and has widespread distribution. Belt-tranect surveys showed Holothuria leucospilota is among the most frequently occurring species both during day time (58\%) and night time (75\%). The Dilasag sampling station had the most diverse species (0.71) while the Dipaculao sampling station had the densest species of Holothuria leucospilota $\left(10,014\right.$ in $\left.\cdot \mathrm{ha}^{-1}\right)$ and abundant $(95.91 \%)$ species.
\end{abstract}

\section{Keywords}

Sea Cucumber, Distribution, Diversity, Abundance, Intertidal Zone

\section{Introduction}

Sea cucumbers are marine animals that live from nearshore habitats to the greatest depths. These are known as beche de mer or trepang when dried or 
processed and are valued for their different economic uses (e.g. delicacy, traditional medicine, source of protein and fatty acids, antiviral, antitumoral and anticancerous, etc.) [1] [2]. The expanding international markets for these species ranked the Philippines as the $2^{\text {nd }}$ major producer and exporter in the world, $2^{\text {nd }}$ to Indonesia, with catches of around 20,000 tonnes (live) per year [3].

In the Philippines, sea cucumber collection forms part as source of livelihood for coastal communities. Collections were usually done in shallow waters but the increase in demand for these species resulted in the collection of smaller size conducted in deeper waters [4] [5]. These obvious signs of stock depletion due to fishing pressures have led to the issue of species extinction before a particular sea cucumber will be recorded.

In Aurora, anecdotal records revealed that sea cucumber trade already exists in the province in the late 60 's and yet there is no inventory of species ever been conducted nor data on its distribution, diversity and abundance been recorded. Therefore, there is the need to create a baseline database for sea cucumber resources in the province before a particular sea cucumber will become extinct. This serves bases for the formulation and implementation of sustainable management strategies.

This study was conducted to provide baseline data on the species distribution, diversity and abundance of sea cucumber in the intertidal zones of Aurora, Philippines. This provided a list of sea cucumber species and their distribution through timed-search survey; determined the diversity and abundance of sea cucumber species through transect survey; and evaluated the population structure of the intertidal sea cucumber resource.

\section{Materials and Methods}

\subsection{Timed-Search Survey}

A preliminary survey was conducted in six intertidal zones (Baler, Dipaculao, Dinalungan, Casiguran, Dilasag, Dingalan) (Figure 1). A one-hour timed search method covering a distance of approximately $1 \mathrm{~km}$ over a $10-\mathrm{m}$ wide area was employed to obtain a complete list of intertidal species.

All species encountered during a one hour walk were photographed (ventral and dorsal sides) in situ using Canon PowerShot D20; weighed up to the nearest gram using a digital weighing scale; measured for the total body length (from mouth to anus) and maximum width up to the nearest $\mathrm{cm}$; identified based on external morphology (body shape, types and number of tentacles and arrangement of papillae and podia), and identification keys [5]; counted and listed on a field notebook.

\subsection{Belt Transect Survey}

Four sampling stations were selected out of the six intertidal zones surveyed based on the presence of seagrass beds, varied substrates (coralline, sandy, muddy sand and rocky) within a station and availability of wide intertidal zone 


\section{Province of Aurora}

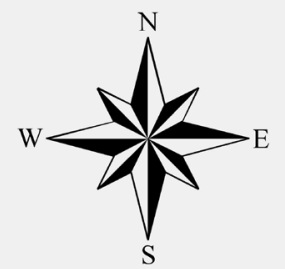

Coordinate System: WGS 1984 UTM Zone 51N Projection: Transverse Mercator

Datum: WGS 1984

False Easting: 500,000.0000

False Northing: 0.0000

Central Meridian: 123.0000

Scale Factor: 0.9996

Latitude Of Origin: 0.0000 Units: Meter

Figure 1. Location of the study sites in colored parts.

for the establishment of belt transects. One sampling station each in the towns of Baler, Dipaculao, Dingalan and Dilasag was established.

Three replicates of $500 \mathrm{~m}^{2}$ belt transects were laid perpendicular and parallel to the intertidal zone, 10 meters apart, covering a total of $1500 \mathrm{~m}^{2}$ per sampling station. Each belt transect was surveyed by four observers going along in one direction parallel to its length. All sea cucumber species found inside were photographed, measured, identified, counted and listed on the field notebook. Representative samples for each species were collected and preserved.

All surveys were conducted during the months of February to June 2013 once on day time and once on night time during the lowest tide. The GPS coordinates of each intertidal zone were taken for mapping purposes using Garmin Etrex-10.

\subsection{Data Analysis}

The following formulae were used in the analysis of data: 
The species frequency was obtained from the index $(C)$ :

$$
C=\frac{P}{N} \times 100
$$

where:

$P=$ number of quadrats containing the species.

$N=$ total number of quadrats.

The species diversity was computed using Simpson's Diversity Index $\left(D_{s}\right)$ :

$$
D_{s}=\frac{\sum n_{i}\left(n_{i}-1\right)}{N(N-1)}
$$

where:

$n_{i}=$ number of individuals of the species.

$N=$ total number of individuals in the sample.

The population density per species was calculated based on the index $(D)$ :

$$
D=\frac{n_{i}}{A}
$$

where:

$n_{i}=$ total number of individuals per species.

$A=$ total area covered in hectares.

The relative abundance per species was based on the index $(\% A b)$ :

$$
\% A b=\frac{D}{\sum D}
$$

where:

$D=$ population density per species.

$\sum D=$ the sum total of all population densities of all species.

\section{Results and Discussion}

\section{Species Distribution, Diversity, and Abundance}

A one-hour timed-search survey conducted in six intertidal zones of Aurora recorded a total of 15 species of sea cucumbers distributed among two Orders (Order Aspidochirotida and Order Apodida) and four Families (Family Holothuriidae, Family Stichopodidae, Family Synaptidae and Family Chirotidae). The scientific name, English name, local name and economic value of these species are included in Table 1.

Most of the species were found in Dilasag (12 species) and Dipaculao (9 species) where both habitats are rich in seagrass beds, muddy sand, rock crevices, corals and coral rubbles which are preferred habitat for sea cucumbers. This is similar with the results obtained in other intertidal zones in the Philippines where most species can be found in seagrass rich habitat [4] [6].

There was only one species found in newly established marine protected area (MPA) in Dingalan with habitat composed of dead corals, coral rubbles, rocks, and very few scattered surviving patches of seagrasses. The number of species in 
Table 1. Sea cucumber species found in intertidal zones of Aurora.

\begin{tabular}{|c|c|c|c|c|}
\hline Scientific Name & $\begin{array}{l}\text { Local } \\
\text { Name }\end{array}$ & Distribution & Habitat & $\begin{array}{l}\text { Economic } \\
\text { Value }\end{array}$ \\
\hline \multicolumn{5}{|l|}{ Order Aspidochirotida } \\
\hline \multicolumn{5}{|l|}{ Family Holothuriidae } \\
\hline Holothurialeucospilota Brandt & Balatuwak & $\begin{array}{l}\text { Baler, Dipaculao, } \\
\text { Dinalungan, } \\
\text { Casiguran, } \\
\text { Dilasag, Dingalan }\end{array}$ & $\begin{array}{c}\text { Crevices, muddy } \\
\text { sand with seagrasses }\end{array}$ & L-M \\
\hline Holothuriacoluber Semper & Patola & Dinalungan & Tidal pool & M \\
\hline Holothuriahilla Lesson & Rotong & $\begin{array}{l}\text { Casiguran, } \\
\text { Dilasag }\end{array}$ & $\begin{array}{l}\text { Crevices and } \\
\text { seagrass beds }\end{array}$ & VL \\
\hline Holothuria impatiens Forskal & Sunlot & Dilasag & Seagrass beds & NC \\
\hline Holothuriafuscocinerea Jaeger & Labuyo & Dilasag & Seagrass beds & $\mathrm{L}$ \\
\hline Holothuria sp. & Rotong & $\begin{array}{l}\text { Dipaculao, } \\
\text { Dilasag }\end{array}$ & Seagrass beds & $\mathrm{L}$ \\
\hline Holothuriascabra Jaeger & Putian & $\begin{array}{c}\text { Dipaculao, } \\
\text { Dilasag, Dingalan }\end{array}$ & Seagrass beds & $\mathrm{H}$ \\
\hline Holothuriaatra Jaeger & Itiman & $\begin{array}{c}\text { Baler, } \\
\text { Dipaculao }\end{array}$ & $\begin{array}{l}\text { Sand and } \\
\text { coral rubbles }\end{array}$ & L-M \\
\hline Actinopygaechinites Jaeger & Khaki & $\begin{array}{l}\text { Dipaculao, } \\
\text { Dilasag }\end{array}$ & $\begin{array}{c}\text { Sandand } \\
\text { coral rubbles }\end{array}$ & $\mathrm{H}$ \\
\hline Bohadschiakoellikeri Semper & Lawayan & $\begin{array}{l}\text { Dipaculao, } \\
\text { Dilasag }\end{array}$ & Seagrass beds & $\mathrm{M}-\mathrm{H}$ \\
\hline Bohadschia sp. & Lawayan & $\begin{array}{l}\text { Dipaculao, } \\
\text { Dilasag }\end{array}$ & Seagrass beds & $\mathrm{M}-\mathrm{H}$ \\
\hline \multicolumn{5}{|l|}{ Family Stichopodidae } \\
\hline Stichopushorrens Selenka & Hanginan & $\begin{array}{l}\text { Dipaculao, } \\
\text { Dilasag }\end{array}$ & $\begin{array}{l}\text { Coral rubbles, sand } \\
\text { and seagrass beds }\end{array}$ & $\mathrm{H}$ \\
\hline Stichophus sp. & Hanginan & $\begin{array}{l}\text { Casiguran, } \\
\text { Dilasag }\end{array}$ & $\begin{array}{l}\text { Coral rubbles, sand } \\
\text { and seagrass beds }\end{array}$ & $\mathrm{H}$ \\
\hline \multicolumn{5}{|l|}{ Order Apodida } \\
\hline \multicolumn{5}{|l|}{ Family Synaptidae } \\
\hline $\begin{array}{c}\text { Synaptamaculata Chamisso } \\
\text { and Eysenhardt }\end{array}$ & Uod & $\begin{array}{l}\text { Dipaculao, } \\
\text { Dinalungan, } \\
\text { Casiguran, } \\
\text { Dilasag, Dingalan }\end{array}$ & $\begin{array}{l}\text { Seagrass beds, } \\
\text { muddy sand, } \\
\text { coral rubbles }\end{array}$ & VL \\
\hline \multicolumn{5}{|l|}{ Family Chiridotidae } \\
\hline Chiridotid sp. & Uod & Dilasag & Seagrass beds & $\mathrm{NC}$ \\
\hline
\end{tabular}

Based on Olavides 2010: H (high) $=\mathrm{P} 1000-4000 / \mathrm{kg}, \mathrm{M}($ medium $)=\mathrm{P} 500-1000 / \mathrm{kg}, \mathrm{L}(\mathrm{low})=\mathrm{P} 100-$ $500 / \mathrm{kg}$, VL (very low) $\leq$ P100/kg; NC (non-commercial).

this MPA was less than the species found in open access areas such as in Dinalungan (3 species), Baler ( 2 species) and Casiguran ( 3 species) which have combinations of habitat e.g. tidal pools, coral rubbles, sand, boulders, rock crevices 
and patches of seagrasses.

The number of species found in intertidal zone of Aurora comprises 15\% of the 100 species found in the Philippines [5]. This is fewer than those found in taxonomic studies conducted in other parts of the country [4] [7] [8]. However, this present study does not include species that could be found in deeper waters. It would also be worthy to emphasize that two species (Holothuria scabra and Stichopus sp.), which are listed during the 2002 Convention on International Trade in Endangered Species of Wild Fauna and Flora (CITES) as threatened species, are still present in Aurora.

The frequency data of the species obtained from transect surveys revealed that Holothurialeucospilotawas present in all sampling stations. This species was most frequently occur-ring both during the day (58\%) and night (\%) (Table 2). Most sea cucumber species especially the Holothuriidae family are nocturnal thus it can be noted that only few were found during the day.

The presence of most number of species in Dilasagis attributed to the varied habitat in the area since different species prefer specific habitat [9]. In addition, the presence of few species in Dingalan could be due to the coral rubble substrate with very few to almost none surviving patches of seagrasses.

The species diversity was computed based only on the data obtained during the night time transect survey. Table 3 showed that the station with the most diverse species was Dilasag (0.71) while Dipaculao (0.01) had the least. Although there were three species found in Dipaculao compared with Baler (2 species) and Dingalan (2 species), the enormous population of Holothurialeucospilota as compared to Bohadschia koellekeri and Bohadschia sp. lowers the species diversity

Table 2. Sea cucumber species found per sampling station during transect surveys.

\begin{tabular}{|c|c|c|c|c|c|c|c|c|c|c|}
\hline \multirow[t]{2}{*}{ Species Name } & \multicolumn{2}{|c|}{$\begin{array}{l}\text { Baler } \\
\text { (rock } \\
\text { crevices } \\
\text { and } \\
\text { seagrass } \\
\text { beds) }\end{array}$} & \multicolumn{2}{|c|}{$\begin{array}{l}\text { Dipaculao } \\
\text { (rock } \\
\text { crevices, } \\
\text { seagrass } \\
\text { beds, } \\
\text { muddy sand) }\end{array}$} & \multicolumn{2}{|c|}{$\begin{array}{l}\text { Dilasag } \\
\text { (rock } \\
\text { crevices, } \\
\text { seagrass beds } \\
\text { muddy sand, } \\
\text { coral rubbles) }\end{array}$} & \multicolumn{2}{|c|}{$\begin{array}{c}\text { Dingalan } \\
\text { (rock crevices, } \\
\text { very few patches } \\
\text { of seagrasses, } \\
\text { muddy sand, } \\
\text { coral rubbles) }\end{array}$} & \multicolumn{2}{|c|}{$\begin{array}{c}\text { Species } \\
\text { Frequency } \\
\text { (\%) }\end{array}$} \\
\hline & Day & Night & Day & Night & Day & Night & Day & Night & Day & Night \\
\hline Holothuria leucospilota & +++ & ++ & + & +++ & + & + & ++ & +++ & 58 & 75 \\
\hline Holothuria hilla & & & & & & + & & & 0 & 8 \\
\hline Holothuria fuscocinerea & & & & & & + & & & 0 & 8 \\
\hline Holothuria scabra & & ++ & & ++ & & & & + & 0 & 41 \\
\hline Bohadschia koellekeri & & & & & & +++ & & & 0 & 25 \\
\hline Bohadschia sp. & & & & + & & & & & 0 & 8 \\
\hline Stichopus horrens & & & & & & +++ & & & 0 & 25 \\
\hline Synapta maculata & & & ++ & ++ & + & +++ & & & 25 & 41 \\
\hline Chiridotid $s p$. & & & & & & + & & & 0 & 8 \\
\hline
\end{tabular}

$+++=$ three transects $500 \mathrm{~m}^{2}$ each. 
Table 3. Species diversity ( $D s)$ of sea cucumbers per sampling station.

\begin{tabular}{|c|c|c|c|c|c|c|c|c|}
\hline \multirow[t]{2}{*}{$\begin{array}{l}\text { Species } \\
\text { Name }\end{array}$} & \multicolumn{2}{|c|}{$\begin{array}{c}\text { Baler } \\
\text { (rock crevices } \\
\text { and } \\
\text { seagrass beds) }\end{array}$} & \multicolumn{2}{|c|}{$\begin{array}{l}\text { Dipaculao } \\
\text { (rock crevices, } \\
\text { seagrass beds, } \\
\text { muddy sand) }\end{array}$} & \multicolumn{2}{|c|}{$\begin{array}{l}\text { Dilasag } \\
\text { (rock crevices, } \\
\text { seagrass beds, } \\
\text { muddy sand, } \\
\text { coral rubbles) }\end{array}$} & \multicolumn{2}{|c|}{$\begin{array}{c}\text { Dingalan } \\
\text { (rock crevices, } \\
\text { very few } \\
\text { seagrasses, } \\
\text { muddy sand, } \\
\text { coral rubbles) }\end{array}$} \\
\hline & $\mathbf{N}$ & $\mathrm{n}(\mathrm{n}-1)$ & $\mathbf{N}$ & $\mathrm{n}(\mathrm{n}-1)$ & $\mathbf{N}$ & $\mathrm{n}(\mathrm{n}-1)$ & $\mathbf{N}$ & $n(n-1)$ \\
\hline Holothuria leucospilota & 9 & 72 & 1506 & $2,266,530$ & 2 & 2 & 17 & 272 \\
\hline Holothuria hilla & 0 & 0 & 0 & 0 & 3 & 6 & 0 & 0 \\
\hline Holothuria fuscocinerea & 0 & 0 & 0 & 0 & 3 & 6 & 0 & 0 \\
\hline Holothuria scabra & 2 & 2 & 0 & 0 & 0 & 0 & 1 & 0 \\
\hline Bohadschia koellekeri & 0 & 0 & 8 & 56 & 23 & 506 & 0 & 0 \\
\hline Bohadschia sp. & 0 & 0 & 1 & 0 & 0 & 0 & 0 & 0 \\
\hline Stichopus horrens & 0 & 0 & 0 & 0 & 4 & 12 & 0 & 0 \\
\hline Synapta maculata & 0 & 0 & 0 & 0 & 9 & 72 & 0 & 0 \\
\hline Chiridotid sp. & 0 & 0 & 0 & 0 & 2 & 2 & 0 & 0 \\
\hline$\sum \mathrm{n}(\mathrm{n}-1)$ & & 74 & & 266,586 & & 606 & & 272 \\
\hline Total (N) & & 11 & & 1515 & & 46 & & 18 \\
\hline Species Diversity $(D s)$ & & 0.33 & & 0.01 & & 0.71 & & 0.11 \\
\hline
\end{tabular}

value. The large population of Holothuria leucospilota has increased the probability that two species randomly gathered in Dipaculao sampling station will belong to this same species.

The Dilasag sampling station revealed five species with low to high economic values and two species of non-commercial to low economic values. This is because of the presence of seagrass beds, coral rubbles, rock crevices and muddy sand habitats. These habitats served as shelter and source of food for several species. In addition, these species which were small were spared from gathering since most of the sea cucumber gatherers in this area prefer larger size species collected from open waters through skin diving and compressor diving.

The density and percent abundance for each species per sampling station showed that Holothurialeucospilota both in Dipaculao (10,014 ind.ha ${ }^{-1}$, 99.09\%) and Dingalan (113 ind.ha ${ }^{-1}$, 94.96\%) and Bohadschia koellekeri in Dilasag (153 ind.ha ${ }^{-1}, 50.1 \%$ ) is high (Figure 2). Low densities and \% abundance of $H$. leucospilota was observed in Baler (60 ind $\left.\cdot \mathrm{ha}^{-1}, 82.19 \%\right)$, B. koellekeri in Dipaculao (53 ind $\left.\cdot \mathrm{ha}^{-1}, 0.52 \%\right)$ and Synapta maculata both in Dilasag (113 ind.ha ${ }^{-1}$, 19.6\%) and Dipaculao (33 ind.ha ${ }^{-1}, 0.33 \%$ ).

The density of all other species in all sampling stations ranges from 0 to 26 ind.ha ${ }^{-1}$ (Figure 2). Although the density of some species is low (less than 100 ind $\cdot \mathrm{ha}^{-1}$ ) it is still alarming that most of the sea cucumber species were within the critical level (less than $30 \mathrm{ind}_{\mathrm{h}} \mathrm{h}^{-1}$ ) for the population to reproduce [10] and 
may imply fishing pressures within the sampling stations. It would be worthwhile to note that sea cucumbers have late maturity, density-dependent reproduction and low rates of recruitment such that even without fishing pressure it would take 50 years to rebuild an overexploited fishing grounds [3].

The high density of Holothuria leucospilota in Dipaculao $\left(10,014\right.$ ind $\left.\cdot \mathrm{ha}^{-1}\right)$ as compared to recorded data in Madagascar (5000 ind.ha ${ }^{-1}$ ) [9] can be attributed to the rich seagrass beds, muddy sand substrate with coral rubble and rock crevices with algae which are preferred habitat for this species (Figure 2). Aside from this, the low economic value may have spared this species from fishing pressures allowing them to reproduce in the area.

Pooled results for all sampling stations revealed that $H$. leucospilota had a high level of density and \% abundance (2556 ind.ha $\left.{ }^{-1}, 95.91 \%\right)$ while $B$. koelllekeri falls within the category of low level density (51 ind $\left.\cdot \mathrm{ha}^{-1}, 1.91 \%\right)$ (Figure 3). The rest of the species were within the critical level. In the absence of fishing pressures, sea cucumbers may occur on Indo-Pacific reef flats at densities

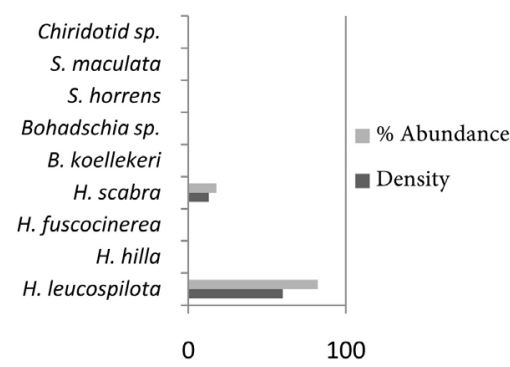

(a)

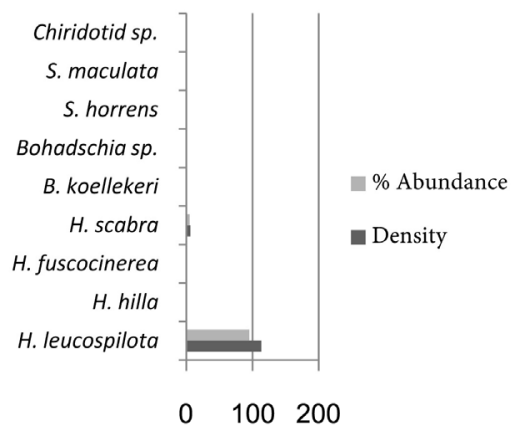

(c)

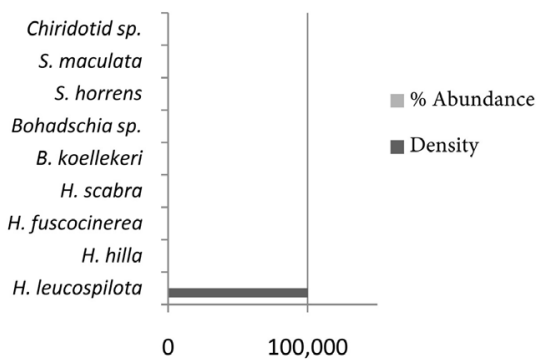

(b)

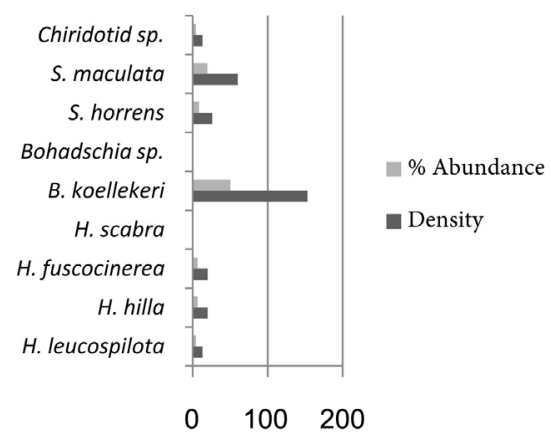

(d)

Figure 2. Density $(D)$ and relative abundance (\%) of sea cucumber per species in (a) Baler; (b) Dipaculao; (c) Dilasag; (d) Dingalan.

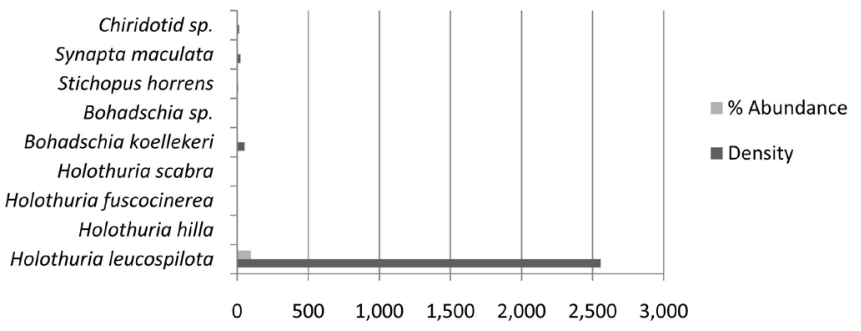

Figure 3. Pooled density and relative abundance (\%) per species in all sampling stations. 
over 35 per square meter or 350,000 ind $\cdot \mathrm{ha}^{-1}$ [3]. The data obtained in this study, therefore, show an obvious overexploitation of sea cucumber resources in the province.

\section{Conclusion}

Based on these results, the following conclusions are drawn: The intertidal zones of Aurora contain a variety of sea cucumber species with economic value, most of the sea cucumber species found in Aurora belong to Family Holothuriidae which are nocturnal species and are of high to medium economic value; Dilasag sampling station has the most diverse species because of its wide habitat rich in seagrass beds, coral rubbles and rock crevices; threatened species, Holothuria scabra and Stichopus sp. are present in Aurora but their density is in the critical level to repopulate, the Dipaculao sampling station showed Holothuria leucospilota as the densest and most abundant species because of rich seagrass beds, algae, coral rubbles and rock crevices which are preferred habitat for this species, and the low density and abundance of species with high to medium economic value (Holothuria atra and Stichopus horrens) imply a low rate of recruitment of these species.

\section{Recommendation}

For a more comprehensive inventory of sea cucumber species found in Aurora waters, the following are recommended: The inventory must include species found in deeper waters, and sampling for 12 months must be conducted to cover all species that were juvenile during the conduct of this study and were obscured from view within sediments, crevices and corals.

\section{Acknowledgements}

We would like to extend our heartfelt gratitude to CHED for funding this study, to PCAARRD, UPMSI and collaborating higher education institutions for their comments and suggestions for the improvement of this research, to all Municipal Mayors of the six coastal towns of Aurora for accommodating us in their respective municipality; and to the then Research and Development Services Office Director, Dr. Eutiquio L. Rotaquio, for guiding us in the processing of important documents needed for fieldwork activities.

\section{Conflicts of Interest}

The authors declare no conflicts of interest regarding the publication of this paper.

\section{References}

[1] Choo, P.S. (2008) Population Status, Fisheries and Trade of Sea Cucumbers in Asia. FAO Fisheries and Aquaculture Technical Paper 516.

[2] James, D.B. (2001) Twenty Sea Cucumbers from Seas around India. Naga. The 
ICLARM Quarterly, 24, $5 \mathrm{p}$.

[3] Bruckner, A.W., Johnson, K.A. and Field, J.D. (2003) Conservation Strategies for Sea Cucumbers: Can CITES Appendix II Listing Promote Sustainable International Trade? SPC Beche-de-mer Information Bulletin \# 18.

[4] Olavides, R.D., Edullantes, C.M.A. and Juiñio-Meñez, M.A. (2010) Assessment of the Sea Cucumber Resource and Fishery in the Bolinao-Anda Reef System. Science Diliman, 22, 1-12.

[5] Schoppe, S. (2000) Sea Cucumber Fishery in the Philippines. SPC Bêchedemer Information Bulletin, 13, 10-12.

[6] Shiell, G. (2004) Field Observations of Juvenile Sea Cucumbers. SPC Bêchedemer Information Bulletin, 20, $6 \mathrm{p}$.

[7] Kerr, A.M., Netchy, K. and Gawel, A.M. (2006) Survey of Shallow-Water Sea Cucumber of the Central Philippines. University of Guam Marine Laboratory, Technical Report No. 119.

[8] Reyes-Leonardo, L.D. (1984) A Taxonomic Report of Shallow-Water Holothurians of Calatagan, Batangas. The Philippine Journal of Science, 113, 3-4.

[9] Purcell, S.W., Samyn, Y. and Conand, C. (2012) Commercially Important Sea Cucumbers of the World. FAO Species Catalogue for Fishery Purposes, No. 6. Rome.

[10] Purcell, S.W., Gossuin, H. and Agudo, N.N. (2009) Status and Management of the Sea Cucumber Fishery of La Grande Terre, New Caledonia. Programme ZoNeìCo. World Fish Center Studies and Reviews No. 1901. The World Fish Center Penang, Malaysia. 138 p. 